\title{
BABI DALAM BUDAYA PAPUA \\ (Pig in The Papua Culture)
}

\author{
Hari Suroto \\ Balai Arkeologi Jayapura \\ hariprimitiveart@gmail.com
}

\begin{abstract}
The pig is an integral part of the culture in the highlands of Papua. Nevertheless, to this day still happening cross of opinion among experts about when the first swine entered in Papua. This paper will discuss the beginning of pigs in Papua and Papuan cultural values associated with the presence of a pig. Data was collected with a literature study, in this paper used descriptive qualitative method. Beginning of the presence of swine in Papua brought by Austronesian speakers. Pig bones found in cave sites north coast of Papua. The presence of pigs in Papua are very influential in Papuan culture.
\end{abstract}

Keywords: Pig, Papua, Culture value

\begin{abstract}
ABSTRAK
Babi merupakan bagian yang tak terpisahkan dari budaya di daerah dataran tinggi Papua. Meskipun demikian, sampai hari ini masih saja terjadi persilangan pendapat antar para ahli mengenai kapan pertama kali babi masuk di Papua. Tulisan ini akan membahas awal mula babi di Papua dan nilai-nilai budaya Papua yang terkait dengan keberadaan babi. Teknik pengumpulan data dilakukan dengan studi kepustakaan, dalam tulisan ini digunakan metode deskriptif kualitatif. Awal mula keberadaan babi di Papua dibawa oleh penutur Austronesia. Tulang-tulang babi ditemukan di situs-situs gua pesisir utara Papua. Keberadaan babi di Papua sangat berpengaruh pada budaya Papua.
\end{abstract}

Kata kunci: babi, Papua, nilai budaya

Tanggal masuk : 17 April 2014

Tanggal diterima : 2 Juni 2014 


\section{PENDAHULUAN}

Kehadiran manusia pertama kali di Papua sekitar 50000 tahun yang lalu, tetapi hewan mamalia yang diintroduksi baru tiba belakangan. Kontroversi masih tetap ada perihal waktu kedatangan babi pertama, suatu unsur integral dalam banyak budaya lokal. Babi yang ada di Papua saat ini dikenal sebagai jenis Sus Scrofa Papuensis. Babi merupakan bagian yang tak terpisahkan dari budaya di daerah dataran tinggi Papua. Meskipun demikian, sampai hari ini masih saja terjadi persilangan pendapat antar para ahli mengenai kapan pertama kali babi masuk di Papua.

Waktu yang diajukan sebagai saat pertama kali masuknya babi ke Papua adalah sekitar 10000 tahun yang lalu, tetapi bukti lain mengajukan 6000 tahun yang lalu, namun belum dapat dipastikan secara definitif. Dengan demikian jenis babi yang kini sudah indigenous atau asli kemungkinan adalah persilangan antara babi hutan biasa, Sus scrofa dan yang kemudian datang atau diintroduksi dari Sulawesi yakni babi hutan Sulawesi, Sus celebensis, yang dahulunya merupakan jenis endemik Sulawesi. Babi-babi ini dipelihara dan hingga kini masih merupakan simbol status dan sumber kemewahan atau kekayaan untuk semua daerah di pedalaman pada dataran tinggi (Muller, 2005:170).

Meski telah ditemukan tulang babi dari zaman pra-Austronesia di beberapa situs arkeologi di Papua New Guinea, penemuan tersebut belum mendapat pengakuan internasional tentang keabsahannya. Walau hasil temuan itu belum sepenuhnya diakui, namun berbagai pihak setidaknya sepakat bahwa apabila memang telah ada babi di Papua diperkirakan terbagi atas dua fase. Fase pertama terjadi sekitar 6000 tahun yang lalu-yang berarti, sebelum orang Austronesia. Fase kedua adalah masa masuknya babi dan penyebarannya secara besar-besaran sebagai hewan hasil domestikasi (hewan yang sudah dijinakkan).

Kemungkinan besar hal ini terjadi ketika ada babi-babi liar yang berhasil melintasi lautan dan sampai di Papua. Atau, mungkin saja babi-babi ini dibawa oleh imigran tak dikenal yang tiba di Pulau Papua sesudah kedatangan orang Papua namun sebelum kedatangan orang Austronesia. Atau ada kemungkinan juga bahwa babibabi itu dibawa masuk oleh orang Papua sendiri dalam kurun waktu yang relatif belum terlalu lama. Dikemukakan bahwa barangkali ada orang Papua yang mengadakan migrasi kembali ke tiga wilayah di Indonesia: Halmahera, Alor dan Timor dan saat kembali ke Papua, mereka membawa babi-babi dari ketiga tempat ini bersama mereka.

Dengan berbagai kemungkinan jawaban seperti dipaparkan di atas, tetap saja belum ada satu jawaban pun yang benar-benar diterima dan dianggap sebagai jawaban yang 'memuaskan' terhadap pertanyaan 'kapan babi pertama kali masuk di Papua'. Terlepas dari semua itu, semua data penelitian ilmiah tentang 'masuknya babi di Papua' selalu mengindikasikan waktu di atas 4000 tahun yang lalu. Dengan kata lain, tak ada data ilmiah tentang keberadaan babi di Papua sebelum 4000 tahun yang lalu (Muller, 2008:56). Walaupun belum ada waktu pasti tentang kapan pertama kali babi masuk ke dataran tinggi Papua, tetap bisa dipastikan bahwa babi (bersama-sama dengan anjing dan ayam) dibawa masuk ke Papua oleh kelompok migran Austronesia (Muller, 2008:25) pada 1500 hingga 1000 SM (Suroto, 2010: 55).

Babi di berbagai tempat di Papua tidak hanya sekedar sebagai sumber pendapatan belaka. Babi juga menjadi "simbol" status kekayaan. Babi dipergunakan dalam acara 'tukar 
daging babi' dan dagingnya selalu menjadi menu utama dalam setiap acara pesta jamuan yang mereka adakan.

Babi adalah sumber protein hewani dan bagian dari ritual. Babi peliharaan telah dan tetap menjadi simbol prinsip nyata akan kemakmuran material di wilayah pegunungan Papua. Pembantaian sejumlah besar babi masih merupakan bagian penting dalam ritual setempat, sebagai tolak ukur kemakmuran sosial dan ekonomi. Tradisi menyantap babi telah menjadi ikatan sosial dan religi bagi penduduk Papua secara luas. Pembagian daging babi yang sudah dimasak menentukan besarnya nilai pentingnya tradisi mereka dalam melaksanakan ikatan antara klan. Sepanjang perayaan masyarakat Papua di dataran tinggi akan mengkonsumsi daging dalam jumlah besar, namun tidak demikian halnya di waktu-waktu lainnya.

Di dataran tinggi, mengebiri babi jantan dengan pisau bambu saat baru berusia beberapa minggu adalah hal umum. Babi jantan yang dikebiri biasanya mudah diatur, jauh lebih mudah bagi wanita untuk mengurusnya. Hanya sejumlah kecil babi jantan yang tidak dikebiri demi kepentingan pembiakan. Babi hutan liar jarang ditemukan dekat kawasan pemukiman untuk dijadikan pejantan bagi ternak betina.

Dalam tradisi masyarakat pegunungan Papua, babi menjadi simbol kekayaan, bahkan lambang kekuasaan. Babi merupakan prasyarat utama dalam setiap pesta kawin maupun pesta jamuan. Untuk pesta kawin, babi termasuk mas kawin yang sangat penting nilainya. Dalam jamuan, daging babi dibagi-bagikan sebagai simbol persaudaraan dan persekutuan. Memasak babi serta memerciki para tamu dengan darah babi sebagai tanda persahabatan.

Tulisan ini akan membahas awal mula babi di Papua dan nilainilai budaya Papua yang terkait dengan keberadaan babi. Teknik pengumpulan data dilakukan dengan studi kepustakaan, dalam tulisan ini digunakan metode deskriptif kualitatif.

\section{Nilai Sakral Babi}

Orang Dani mengadakan pesta jamuan besar-besaran, banyak babi yang disembelih, untuk menghormati tamunya. Pada pesta jamuan itu, para tetua adat dan tamu bersama-sama memakan hati babi sebagai bagian dari ritual perlambang adanya ikatan persaudaraan. Pada akhirnya, para tetua adat Dani memercikkan darah babi.

Bagi orang Yali, babi memiliki nilai yang lebih tinggi daripada ubi jalar. Babi mempunyai arti dan nilai secara mitologis dan digunakan untuk upacara-upacara adat, sebagai alat pembayaran dan merupakan satusatunya sumber daging yang tetap. Babi adalah satu-satunya binatang piaraan rumah yang dikenal orang Yali, selain beberapa ekor anjing. Semakin banyak babi yang dimiliki seorang pria, semakin besar kekayaannya dan semakin tinggi statusnya. Istri dibeli dengan babi, persahabatan dan hubungan dagang dipererat dengan pemberian babi dan kesalahan diselesaikan dengan pembayaran babi pula. Hal menjaga dan memelihara babi adalah urusan wanita. Babi sedemikian penting artinya bagi orang Yali, sehingga pada situasi-situasi tertentu untuk mempertahankan hidup seekor anak babi juga disusui oleh seorang wanita sebagaimana anak kecil. Babi juga tidur di bagian belakang pondok kaum wanita.

Perang suku yang kerap terjadi di Timika didamaikan dengan mengorbankan beberapa ekor babi perdamaian. Sedangkan di masyarakat Suku Arfak babi perdamaian banyak digunakan dalam menyelesaikan 
sengketa perzinahan (Mulyadi, 2012: 93). Untuk mengatasi permusuhan atau konflik di atas adalah dengan cara menggunakan babi perdamaian. Laki-laki yang melakukan kesalahan atau perzinahan menyiapkan babi di halaman rumahnya. Pada waktu suami dan istri korban datang menyerang langsung membunuh babi dengan panah dan parang sampai mati, tubuh babi dipotong sampai hancur. Setelah itu kepala suku turun tangan untuk mendamaikan kedua belah pihak yang bersengketa dan dijamin tidak terjadi lagi perselisihan, Ini artinya, emosi kemarahan kepada pelaku dialihkan kepada ternak babi sehingga tidak terjadi korban manusia.

Bagi Suku Kamoro, perburuan babi masih merupakan bagian dari ritual inisiasi. Selama tahun awal dari periode ritual ini (setiap empat sampai enam tahun), sekelompok lelaki Kamoro pergi keluar kampung untuk berburu babi liar di lokasi-lokasi tempat dimana mereka telah menebang pohon-pohon sagu. Saat mereka berburu, ukiran kayu berbentuk babi kecil diberi 'makan' sagu sebagai alat magis agar menarik perhatian babibabi liar. Dengan kegembiraan yang luar biasa, wanita-wanita di kampung akan menyambut para lelaki yang berhasil membawa pulang potonganpotongan besar daging babi yang mereka bunuh (Muller, 2011:19).

Hewan babi bertalian dengan mitos suku Marind-anim dan merupakan suatu lambang bagi beberapa marga mereka. Salah satu makhluk gaib khusus, yakni Nazr, menjadi pelindung sekaligus pembunuh babi-babi. Pelangi terjadi dari darah seekor babi besar yang memercik ke langit. Suku Marind memelihara lebih banyak babi sebagai makanan dalam upacara-upacara dibandingkan dengan penduduk Papua pesisir selatan lainnya: salah satu sumber menjelaskan bahwa 30 hingga 50 ekor babi dibunuh dalam satu hari upacara ritual. Pesta babi sangatlah penting bagi Suku Marind, digambarkan dalam upacara inisiasi anak laki-laki dan kaum wanita memiliki pesta babi mereka sendiri. Selama pertukaran makanan diantara sekeluarga dan klan, babi-babi merupakan aset utama tetapi tidak harus ada. Babi juga terkait erat dengan ilmu sihir, termasuk peperangan. Babi peliharaan diberi nama-nama berdasarkan nama tempat-tempat yang dikunjungi ketika pergi mengayau. Suku Marind juga menghubungkan babi dengan pemujaan arwah leluhur mereka. Babibabi dipotong di atas kuburan dengan darah menetes di atas mayat. Pesta babi merupakan penghargaan terakhir bagi yang meninggal, kemudian kuburan tersebut menjadi sesuatu yang terlupakan. Di Pulau Kimaam, babi dibunuh untuk upacara ritual anak-anak, dimana anak lelaki duduk di atas babi, saat hewan itu disembelih dengan satu kali ayunan kapak (Muller, 2011:20).

Kepercayaan suku Eipomek menyebutkan bahwa babi adalah salah satu leluhur. Sebagai bentuk pertalian antara klan tersebut dengan leluhur ini, sekitar sepertiga dari suku Eipomek dilarang mengkonsumsi babi. Legenda masyarakat pegunungan yang lain mengisahkan bahwa babi-babi bersama dengan manusia keluar dari gua leluhur di Lembah Baliem. Diyakini bahwa babi dapat digunakan sebagai korban persembahan bagi arwah, menggantikan manusia. Apabila kaum wanita atau anak-anak Suku Yali tidak sengaja mendengar kata-kata sakral yang terlarang, maka telinga mereka harus dibersihkan dengan lemak babi.

Dalam kehidupan sehari-hari Suku Yali tidaklah memakan babi. Babi adalah sesuatu yang jarang dan berharga di daerah Yalimo yang agak tandus (Reuter, 2010:152). Babi hanyalah dimakan pada acara-acara khusus seperti kemenangan perang, 
upacara adat dan perkawinan. Untuk itu banyak orang yang datang dan makanan dimasak dalam sebuah lobang di tanah dengan bakar batu.

\section{Nilai Ekonomi}

Pentingnya nilai sosial dan ekonomi hewan babi bagi penduduk Papua di dataran tinggi, baik di masa lalu maupun sekarang sangatlah jelas. Untuk memperlihatkan betapa pentingnya, babi-babi kerap diberi nama. Hewan ini juga diklasifikasikan berdasarkan ukuran besar dengan patokan harga tetap dalam perhitungan mata uang lama dari kulit kerang cowrie.

Peters (1965) menyatakan bahwa orang Dani tidak makan daging babi secara reguler. Orang Dani jarang memotong babi hanya dengan tujuan hanya ingin makan dagingnya. Memotong dan memakan babi selalu terikat pada peristiwa sosial yang penting, seperti upacara pembakaran mayat, perkawinan, dan upacara inisiasi. Kecuali kalau babinya mengidap penyakit atau merupakan hasil curian; dalam hal tersebut dagingnya harus dikonsumsi secepat mungkin. Kesempatan memakan babi yang paling sering berulang adalah pada upacara pembakaran mayat. Kesempatan unik lain dimana setiap orang baik laki maupun perempuan ataupun anak memakan babi selama beberapa minggu berturut-turut adalah pada pesta babi besar yang diadakan secara berkala.

Masyarakat Papua di dataran tinggi memelihara babi-babi yang akan dibunuh sewaktu festival atau kesempatan penting lainnya. Ternak babi sangat penting bagi aspek ritual dan kehidupan sosial masyarakat dataran tinggi sementara orang-orang Papua di pesisir selatan hanya berburu babi liar dan kadangkala memelihara anak babi ketika induknya terbunuh. Babi-babi menjadi sumber protein yang lebih berharga di dataran tinggi. Di banyak daerah, mereka dibunuh dengan sebuah busur dan anak panah. Ada kalanya hewan ini dibunuh dengan cara dipukul hingga mati.

Hylkema (1974) menyatakan tentang peranan babi dalam masyarakat Ngalum meskipun, dalam kaitan dengan babi, bukan merupakan hal biasa untuk berbicara tentang kedudukan sosial, namun dalam kaitan tersebut tempat yang diberikan orang kepada babi dalam masyarakat justru demikian maksudnya. Babi memang bermanfaat untuk orang, tetapi di samping itu orang bersedia membuat dirinya berjasa terhadap babi: babi dihormati.

Babi bagi Suku Ngalum merupakan binatang penting dalam berbagai upacara, dan merupakan lambang kedudukan sosial dan ekonomi. Babi diperdagangkan dan berfungsi sebagai mas kawin (Roembiak, 1994:320). Pemimpin adat Suku Mek disebut tonowi, kedudukan sebagai tonowi diperoleh atas upaya sendiri, salah satunya adalah memiliki banyak babi (Yam dan Howay, 1994:249).

Pertukaran babi bagi suku Yali akan menjadi suatu upacara persahabatan. Membagikan potongan daging babi dalam beragam perayaan dapat mempererat ikatan antar individu atau kelompok. Pemberian daging babi akan mendapatkan balasan yang sama atau lebih baik dari penerima di kemudian hari. Selain menciptakan hubungan sosial, babi juga dapat menimbulkan pertikaian.

Babi diberi makan ubi jalar, sehingga bagi masyarakat pig centered tentu saja ubi jalar merupakan tanaman yang sangat berharga (Golson dan Gardner, 1990: 408). Ubi jalar yang dijadikan sebagai pakan babi berkarakteristik umbi besar, kulit pecah-pecah, berserat, rasa tawar, bertekstur keras atau lembek sekali 
(Suroto, 2013:90). Babi dibiarkan tidur di sekitar tempat tinggal pemiliknya, siang hari babi-babi itu dibiarkan berkeliaran mencari makan sendiri.

Tempat terbaik untuk mencari makan adalah kebun-kebun ubi jalar. Meski kebun itu dipagari, babi adalah hewan besar yang cukup pandai. Mereka bisa merobohkan dan menerobos masuk melalui bagian pagar yang rapuh. Bila tertangkap pemilik kebun, babi itu bisa dibunuh. Sehingga kerap menjadi potensi konflik antara peternak babi dan pemilik lahan ubi jalar. Karena semua keluarga memelihara babi dan menggarap kebun ubi jalar, potensi konflik pun kian besar. Peperangan bisa terjadi karena adanya babi-babi yang menerobos kebun-kebun ubi jalar.

Diperlukan waktu sekitar dua hingga tiga tahun bagi ternak babi untuk mencapai maksimal, siap untuk disembelih. Jika selain mencari makan sendiri babi juga diberi makan secara normal maka pertambahan berat badan mencapai 50 gram per hari. Namun bila diberi makan yang mengandung protein, pertambahan berat badannya bisa mencapai setengah kilogam per hari untuk semua ternak babi dengan mengabaikan berat badan ataupun usia. Kondisi ini berlaku pada semua jenis babi kecuali yang sedang menyusui bisa bertambah berat mencapai satu kilogram setiap hari.

Wanita Marind dan Kimaam memelihara semua jenis babi. Babi jantan dikebiri agar menjadi penurut. Babi-babi diperhatikan dan dimanja, bertolak belakang dengan perhatian kepada anjing-anjing pemburu yang handal. Lain halnya dengan kehidupan sosial dan dan aktivitas ritual yang penting bagi suku Me berpusat pada pertukaran harta perolehan seperti babi dan benda berharga lannya dengan kulit kerang-kerangan.

Suku Dani membunuh babi dengan cara menembaknya dari jarak sekitar $10 \mathrm{~cm}$ dengan sebuah anak panah yang diarahkan tepat pada jantungnya. Setelah itu babi dipotongpotong dagingnya sesuai dengan cara yang telah ditentukan adat, lalu dimasak dengan cara menimbunnya dengan batu panas. Guna keperluan itu mereka membuat sebuah lubang dalam tanah berdiameter sampai satu meter. Dasar lubang dilapisi dengan rumput dan daun ubi, dan kemudian dilapisi dengan batu-batu yang membara hingga tampak putih.

Satu keluarga Suku Arfak biasa memelihara babi, dua hingga empat ekor. Babi diperoleh dengan membeli calon induk, pembayaran mas kawin, pembayaran denda adat, dan hadiah. Masing-masing babi diberi nama oleh pemiliknya sesuai dengan latar belakang peristiwa ternak babi tersebut diperoleh atau sesuai dengan warna kulit, besar, dan nama anggota keluarga atau nama lingkungan alam yang ada di sekitar pemukiman setempat. Pemberian nama pada babi akan mengakrabkan hubungan pemilik dengan babi. Babi yang sedang berada jauh dari pemiliknya, bila dipanggil namanya maka akan segera babibabi tersebut berdatangan mendekati orang memanggil namanya (Mulyadi, 2012:94).

Di wilayah dataran tinggi, jumlah babi yang dibunuh secara langsung menjadi tolok ukur tentang seberapa penting orang yang meninggal. Semakin banyak babi yang dipelihara, semakin tinggi pula gengsi serta nilai kekayaan pemiliknya. Sebagian dari kekayaan ini biasanya digunakan untuk memperbanyak jumlah istri yang menandakan meningkatnya poligami termasuk peningkatan status dan pengaruh politik.

Dalam upacara adat suku Dani, seperti perkawinan, kematian, pelantikan kepala suku, penyambutan tamu, pesta panen, dan festival budaya, babi (wam) dan ubi jalar 
dimasak dengan cara "bakar batu" (wam ebe ekho) (Peter, 2001:4). Persiapan bakar batu itu diawali dengan pemanasan batu-batu dalam perapian dan pemotongan babi-babi dalam bagian-bagian kecil. Batubatu yang sudah sungguh panas itu kemudian diambil dengan sebuah 'tang alami" (berupa dua potong kayu) dan diletakkan ke dalam lobang di tanah sebagai lapisan pertama. Di atasnya kemudian diletakkan daun-daun pisang dan kemudian diatasnya lagi lapisan pertama dengan ubi jalar. Sayuran dan bagian-bagian daging babi yang kemudian ditutupi kembali dengan dedaunan. Kemudian ditaruh lapisan kedua batu-batu panas, kemudian dedaunan, lapisan kedua bahan makanan kemudian ditutupi kembali dengan batu-batu panas. Demikianlah seterusnya dan di bagian paling atas batu-batu panas kembali. Bukit batu panas ini kemudian dibiarkan memasak selama dua jam dan kemudian dibuka.

\section{Peralatan Hidup}

Tulang babi dimanfaatkan oleh orang Papua sebagai bahan peralatan hidup. Suku Kombai di Boven Digoel memanfaatkan gigi, taring seri babi sebagai perhiasan tubuh. Cara pembuatannya yaitu pangkal gigi seri dilubangi untuk dijadikan kalung, sedangkan taring babi digunakan untuk hiasan hidung.

Alat tulang babi digunakan sebagai pisau oleh suku Lani di Mamberamo Tengah untuk memotong dan membelah buah merah. Teknik pembuatannya yaitu pemecahan tulang menggunakan alat tumpul. Kemudian dilanjutkan dengan pengerjaan lebih lanjut yaitu teknik pangkas yaitu dengan cara memangkas bagian ujung untuk kemudian dilakukan peruncingan pada distal. Untuk membentuk artefak sesuai dengan yang diinginkan, diperlukan penghalusan melalui penggosokan pada bagian yang digunakan sebagai tajamannya.

Buah merah dipotong menjadi dua menggunakan pisau tulang babi, kemudian daging buahnya dibersihkan hingga tersisa kulit luar. Daging buah berwarna putih kekuningan dan tidak bisa dimakan. Daging buah merah ini dikeruk menggunakan pisau tulang babi. Setelah itu, buah merah dibersihkan langsung dibakar bersama ubi-ubian dalam acara bakar batu dan diletakkan di bagian paling atas. Setelah matang, buah merah belum bisa dimakan, namun masih harus diolah lagi untuk dijadikan kuah sayur. Setelah buah merah dirasa cukup matang, barulah buah merah diperas dan air perasannya direbus untuk dijadikan kuah sayur.

\section{PENUTUP}

Awal mula keberadaan babi di Papua dibawa oleh penuturAustronesia yang bermigrasi ke wilayah ini. Tulangtulang babi ditemukan di situs-situs gua pesisir utara Papua. Pada mulanya babi dipelihara di wilayah pesisir, dalam perkembangan selanjutnya babi berkembang biak dan menyebar ke seluruh daratan Papua. Keberadaan babi di Papua sangat berpengaruh pada budaya Papua. Nilai-nilai budaya yang terkait dengan keberadaan babi yaitu "simbol" status kekayaan, ekonomi, sosial, ritual. 


\section{DAFTAR PUSTAKA}

Brongersma, L.D. 1956. Dieren Van Nieuw-Guinea. Groningen: J. B. Wolters.

Golson, J. dan D. S. Gardner. 1990. Agriculture and Sociopolitical Organization in New Guinea Highlands Prehistory. Annual Review of Anthropology. Vol. 19. HIm. 395-417.

Hylkema, S. 1974. Laki dalam Tas Jala - Orang - dan Gambaran tentang Dunia dari Orang Ngalum (Pegunungan Bintang). s' Gravenhage.

Lekitoo, Hanro Yonathan. 2012. Potret Manusia Pohon. Jakarta: Balai Pustaka.

Muller, Kal. 2008. Mengenal Papua. Daisy World Books.

Muller, Kal. 2005. Keragaman Hayati Tanah Papua. Manokwari: Universitas Negeri Manokwari.

Muller, Kal. 2011. Pesisir Selatan. Daisy World Books.

Mulyadi. 2012. Budaya Pertanian Papua Perubahan Sosial dan Strategi Pemberdayaan Masyarakat Arfak. Yogyakarta: Karta Media.

Peters, H. L. 1965. Beberapa Bab dalam Kehidupan Sosial-religius Suatu Kelompok Dani. Venlo.

Peter, J. 2001. Local Human-Sweet Potato-Pig Systems Characterization and

Research in Irian Jaya, Indonesia. A Secondary Literatur Review. International Potato Center (CIP) Support from ACIAR. HIm. 1-77.

Reuter, Susanne. 2010. Ketika Injil Bersinar di Yalimo. Wahine Germany.

Roembiak, M. D. E. 1994. Masyarakat Ngalum di Daerah Pegunungan Bintang dalam Koentjaraningrat (ed) Irian Jaya Membangun Masyarakat Majemuk. Jakarta: Djambatan. HIm. 313-333.

Suroto, Hari. 2010. Prasejarah Papua. Denpasar: Udayana University Press.

Suroto, Hari. 2013. Revolusi Ubi Jalar di Lembah Baliem dalam Simon Abdi K. Frank dan Bau Mene (ed.), Kebudayaan Papua: Tradisi, Sistem Pengetahuan, dan Pembangunan Jati Diri. Balai Arkeologi Jayapura.

Yaam, P. dan O. Howay. 1994. Masyarakat Mek di Sekitar Danau Paniai dalam Koentjaraningrat (ed) Irian Jaya Membangun Masyarakat Majemuk. Jakarta: Djambatan. HIm. 245-257. 